\title{
An Analysis on Effect of Urban Development Plans on Realization of Sustainable Development of Metropolis of Isfahan
}

\author{
Masoud Taghvaei ${ }^{1}$, Hamid Reza Varesi ${ }^{2} \&$ Masoud Narimani ${ }^{3}$ \\ ${ }^{1}$ Professor of geography and urban planning, University of Isfahan, Isfahan, Iran \\ ${ }^{2}$ Associate Professor of Geography and Urban Planning, University of Isfahan, Isfahan, Iran \\ ${ }^{3} \mathrm{PhD}$ Student of Geography and Urban Planning, University of Isfahan, Isfahan, Iran \\ Correspondence: Masoud Taghvaei, Professor of geography and urban planning, University of Isfahan, Isfahan, \\ Iran. E-mail: m.taghvaei@geo.ui.ac.ir
}

Received: December 10, 2015

Accepted: January 25, 2016

Online Published: January 13, 2016

doi:10.5539/mas.v10n3p1

URL: http://dx.doi.org/10.5539/mas.v10n3p1

\begin{abstract}
Spreading cities and increasing urban population scaled up urban problems and challenges. As a metropolis, Isfahan is faced with many challenges, too, which requires effective and qualitative urban development plans in regards of urban sustainable development framework in order to improving itself. The objective of this research is evaluating status of sustainable development of Isfahan and effect of urban development plan on this city. Therefore, the research data is analyzed and evaluated using quantitative model of TOPSIS regarding objectives and hypotheses of the research. In addition, Entropy and coefficient of dispersion, SPSS, EXCEL and TOPSIS SOLVER software are used in order to dada analysis and ARC GIS software is used to draw and provide maps. Results and findings of analyzing and evaluating this research indicated that urban development flow of Isfahan is an unsustainable flow at both levels of "present situation" and "urban development plan"; most districts in Isfahan are much less prosperous, less prosperous or fairly prosperous. Therefore, in "current condition", $33 \%$ of urban district in Isfahan are at "less prosperous and much less prosperous" level and 37\% of districts are at "fairly prosperous" level; only $30 \%$ of urban district in Isfahan are at "prosperous and very prosperous" level. This condition deteriorated more in urban development plan. In urban development plan of Isfahan, 55\% of urban district of this city are at "less prosperous and much less prosperous" level and $15 \%$ of districts are at "fairly prosperous" level; only $30 \%$ of urban districts of Isfahan are at "very prosperous and prosperous" level. According to this fact that indicatives of this analysis are capitations of urban services' applications, we can conclude that capitation of urban services' applications is reduced in urban development plan and is turned to capitation of residential applications (non-service). Therefore, metropolis of Isfahan is not a sustainable and prosperous city and facilities or public services are not distributed sustainably and concordantly in its urban districts.
\end{abstract}

Keywords: sustainable development, urban development plans, spatial justice, social justice, metropolis of Isfahan

\section{Introduction}

The world's population is going toward urbanization increasingly; in such a way that since the early 21th century (2008) forward, more than half of world's population are living in urban regions (Taghvaei et al., 2015). Regarding this flow, it is anticipated that more than $65 \%$ of world's population are going to live in urban areas by 2025 (Feng et al., 2008); it means these are locations, which consume most resources and produce most wastes and pollutions (Masnavi, 2002). According to speed of urbanization, urban environments will replace natural ecosystems (Pauleit et al., 2005) and this expedite urbanization leads to increasing urban problems and social, economical and environmental inequalities; and its consequences are increasing poverty in cities, environmental pollutions, shortage of urban services and water sources and spreading suburbanization (Pug, 2004). The consequences of expedite urbanization are increasing challenges and social, economical and environmental inequalities in urban regions of under developing countries and urbanization created an extensive domain of heterogeneous conditions (Jenny \& Ericson, 2006).

The metropolis of Isfahan is faced with numerous challenges and it seems that the state of Isfahan is not good. Heretofore, numerous urban development programs and plans are provided for metropolis of Isfahan; but, urban 
challenges are increased and these plans did not lead to urban sustainable development. Still, urban poverty, shortage and unbalanced distribution of public services in urban districts of Isfahan and existence of bereaved and non-prosperous neighborhoods are fundamental and bothering urban challenges in metropolis of Isfahan. This flow can indicates inefficiency of present urban development programs and plans and it emphasizes on and warns about necessity of change in strategies of decision -making systems (urban planning) and decision systems (urban management) of metropolis of Isfahan in urban sustainable development framework. In this regard, the objective of this research is evaluating status of sustainable development of Isfahan city at two levels of "current condition" and "urban development plan", which is analyzed and evaluated using TOPSIS model. The results indicate that Isfahan city is not a prosperous and sustainable city and facilities and urban or public services are not distributed in this city sustainably and concordantly. Unfortunately, this condition is not improved or adjusted in urban development plan of Isfahan and still, Isfahan city is not prosperous at both levels of "current condition" and urban development plan".

The objectives of this research include evaluation of prosperity and sustainable development of Isfahan city. In addition, the hypotheses of this research include: metropolis of Isfahan is not a sustainable and prosperous city and distribution of urban and public services are not fair and sustainable in urban districts of Isfahan. Also, the current urban development plans do not result in improvement of prosperity level and sustainable development of the city of Isfahan.

It should be emphasized that this research is extracted from the geography and urban planning PhD thesis of University of Isfahan titled as "strategic planning of urban sustainable development with emphasis on physical development, case study: metropolis of Isfahan".

\section{The Research Background}

Conducted researches on urban development are examined below:

In a plan titled "urban development strategies of Sofia", Cities Alliance (2001a) examines urban development strategies of Sofia and defines the objective of this plan as reaching to economical efflorescence, social justice and effective governing. It specifies strategies of sustainable development of Sofia city as creating sustainable economical growth, improvement and gradation of effectiveness and efficiency of local authority, improvement of quality and efficiency of urban district's structure, development of tourism and creating sustainable urban incomes.

In an article titled as "sustainable urban development", Moreno and Martinez (2010) consider sustainable development as the main goal of future development of cities and classify sustainable development of cities in three important aspects including sustainability of natural, economical and social environments.

In a research, Masoud and Rana (2011) examine urbanization and problems of urban development of Dhaka in Bangladesh and consider urbanization as a phenomenon which is spreading and growing in this city such as most of under-developing countries. This expedite urbanization had so many negative effects on sustainability of city of Dhaka and created many problems in urban infrastructures, transportation, traffic and environmental pollutions.

In an article, Zahrabi and Mokhtari Malekabadi (2006) examined condition of being developed in districts of Isfahan city using development indicators including economical and infrastructural, cultural, social, educational, hygienic and remedial indicators and concluded that there is no balanced development among urban districts of Isfahan.

In an article, Saberi et al. (2012) prioritized and analyzed development strategies of metropolis of Isfahan by strategic planning approach and concluded that in social, economical, framework and land-use, environmental and access among urban districts of Isfahan, spatial form and structure show spatial imbalance and inequality. They also introduced strategies of spatial justice and equal distribution of facilities and urban services among urban districts of Isfahan.

\section{The Rresearch Scope}

The scope of this research is range of Isfahan city and its urban districts (Figure 1 and Figure 2). Metropolis of Isfahan has 15 urban districts. It is worth to mention that range and frontage area of Isfahan city is 55.072 hectare which 20.034 hectare of that is range area of Isfahan city (Statistic journal of Isfahan city, 2013). 


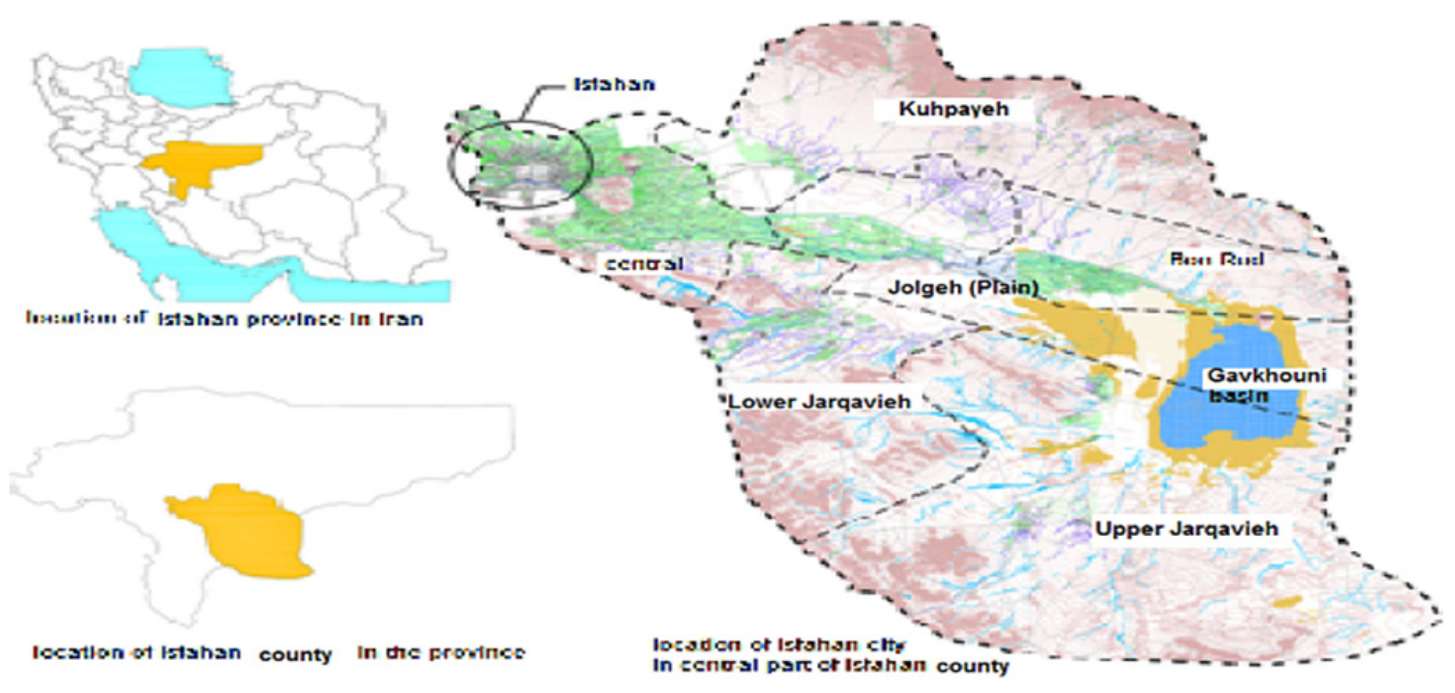

Figure 1. Location of Isfahan city in the country and in the region

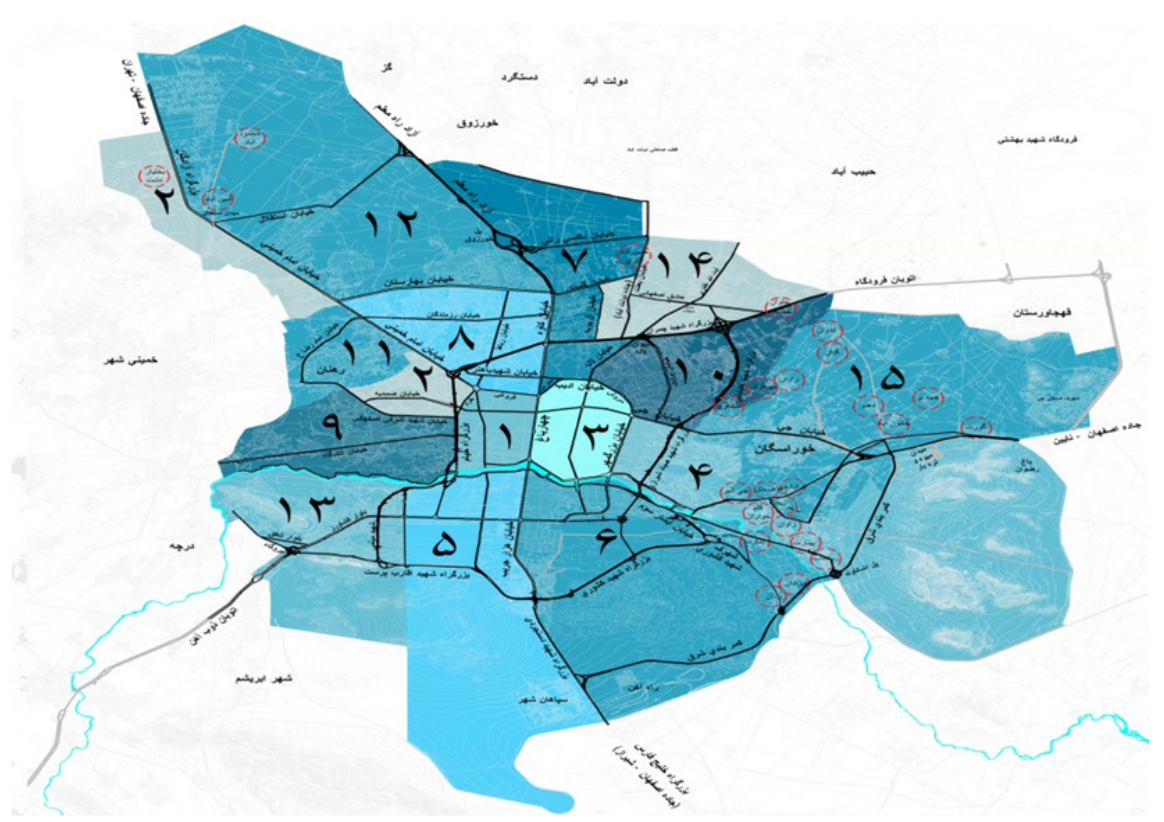

Figure 2. Range of Isfahan city and its urban districts

\section{Concepts, Theoretical Principles and Methods}

\subsection{Urban Sustainable Development}

Developing cities and spreading approach of sustainable development and its concentration on urban settlements put an emphasis on the topic of urban sustainable development; and in recent decades, it noted toward making policy in urban settlements and turned to the guiding principle of policy-making and ruling of city (Hall \& Fifer, 2009). Urban sustainable development is a form of today development which can guarantee continuous development of cities and urban communities for next generations (Taghvaei \& Safarabadi, 2013). Urban sustainable development can be considered as a basis of renewing urban economical, social, cultural and legal structures, which its goal is improving urbanization process and urbanism flow, restoring urban environment, systemizing urban economics and strengthening social and cultural aspects of urban life (Bastanifar \& Sameti, 2004). In the conference of urban future of 21th century, urban sustainable development is defined as improving life quality of a city in ecological, organizational, social and economical criteria without any pressure on ecological capacity of next generations (Gottdiener \& Budd, 2005). One of criteria of urban sustainable 
development is balanced distribution of urban services and facilities; and distribution of urban services should be in a form that helps establishing social justice (Taghvaei \& Kiumarsi, 2011).

\subsection{Social Justice}

In specifying justice, researchers investigated this concept from many various viewpoints and other concepts such as social justice, spatial justice, geographic justice and environmental justice are under influence of multidimensionality of this word (Varethi et al., 2007). David Harvey was the first geographer, who used concept of social justice to help public benefits, to make criterion for income distribution in places, to attribute resources fairly and to obviate essential needs of people (Shokuei, 1999). David Harvey considers geography science as a means to implement social justice and access to a kind of spatial organization and he believes the essential and initial conditions of doing this are having a fair social criterion for defining limits of districts and having another criterion for attributing resources to these districts. The first condition is related to traditional geographic studies or zoning; and about attributing resources, Harvey believes in this logic of Rawels which says the most resources should be attributed to the most bereaved districts (Hataminejad et al., 2008).

\subsection{Spatial Justice}

In contemporary time, the attraction of reaching to a fair society led to forming a spread spectrum of movements of social justice such as economical justice, ethic justice, environmental justice and others. The current belief is that spatial justice can be considered as a capacity for alliance of justice movements under a common cover by accepting social and environmental conditions and introducing them and this spatial justice can help planners and policy-makers to create more sustainable and more reasonable (Prange, 2009). However, some researchers defined spatial justice as only equal access to essential public facilities and considered criterion of measuring justice as level of distance from services. Some others defined spatial justice as equal distribution of services based on needs, tastes and priorities of settlers and standards of providing services (Liao et al., 2009). According to approach of social justice, spatial justice means all settlers should be treated equally, no matter where they live (Tsou et al., 2005).

\section{Techniques and Methods of Analysis}

\subsection{TOPSIS Model}

TOPSIS model is one of common and useful methods among multi-indicator decision-making methods, which is based on calculating the distance of options from ideal positive solution and ideal negative solution (Tghvaei et al., 2011). Huang and Yun proposed this model for the first time in 1981. The theoretical basis of this technique is based on the relation that at first, positive ideals (best condition) and negative ideals (worst condition) are found for each indicators using a series of techniques; and then, the distance of each option from positive and negative ideals will be calculated. The chosen option is the option, which has the least distance from positive ideal and most distance from negative ideal. Scores and grades of TOPSIS are between 0 and 1; so, being close to 1 shows ideality of score for a TOPSIS indicator. This technique is designed in a way that the designer can interfere kind of indicators based on having negative or positive effect on decision-making goal in the model; also, the designer can enter weight and importance of each indicator in the model. The analysis method of TOPSIS is a multi-indicator decision-making method, which its goal is grading and choosing the best option (Hekmatnia \& Mousavi, 2011).

\subsection{Entropy Model}

This model is a criterion for measuring distribution of urban population and distribution of cities in urban classes of a district. Using this model, we can find out level of spatial balance of establishment of population at level of urban, provincial, regional and national networks (Hekmatnia \& Mousavi, 2011). Shanon relative entropy can be used for measuring inequality of population's distribution or occupancy in a metropolis and it has a value between 0 and 1 . The closer the value to 1 , the more balanced the distribution and the closer the value to 0 , the less balanced and the more concentrated the distribution. In other word, the value of one shows a completely balanced value and the value of zero shows a completely imbalanced distribution (Tsai, 2005).

\section{Process of Research and Analysis}

The analysis process in this research is conducted based on objectives, hypotheses and indicators of the research in a systematic process. This process includes five steps and during that, status of sustainable development of metropolis of Isfahan and its urban districts are analyzed and evaluated at two levels of "current condition" and by "effect of urban development plan" using TOPSIS model. In this research, SPSS, EXCEL and TOPSIS SOLVER software are used for analyze data and ARC GIS software is used for draw and provide maps, along with other analysis methods. it should be noted that in this research, status of prosperity from public and urban 
services of Isfahan are evaluated and analyzed in order to investigating and evaluating status of sustainable development in metropolis of Isfahan. In context of the research, level of "prosperity" is used. In addition, purpose of urban development plan is new detailed plan of Isfahan city as the approved urban development plan and criterion of legal act in the city. Meanwhile, according to this fact that town of Khorasgan was joined to metropolis of Isfahan in 2013 and is considered as the $15^{\text {th }}$ district of Isfahan city; but its statistics and information are not anticipated in new detailed plan of Isfahan city. Therefore, its information is not considered analysis process of this research and other 14 urban districts of Isfahan are considered and analyzed. In addition, the $7^{\text {th }}$ and the $14^{\text {th }}$ districts, which are currently considered as two separated urban districts, are not detached in the new detailed plan of the city and their statistics and information are analyzed and presented a urban district.

\subsection{First Step: Indicators of the Research}

Indicators of the research are capitations of urban services' usages including "green spaces, health-remedial, educational, sport, religious cultural, parking lot, entertaining touristic, vocational and higher education, urban equipments, industrial and workshop, transportation and storage, official disciplinary, public services, mixed commercial, crossovers and pathways, other".

\subsection{Second Step: Evaluating Status of Indicators (Capitations of Urban Services' Usages) in Urban Districts of Isfahan}

Values in table 1 indicate status of indicators (capitation of urban services' usages) in each urban district of Isfahan at two levels of "current condition" and "proposed condition" of the urban development plan. According to that, the most and the least capitations of green spaces are related to districts 2 and 9 with values of 43 and 28.2 square meters and districts 1 and 3 with values of 5.35 and 1.13 square meters for each person, respectively. In case of health-remedial usage, districts 5 and 3 have the most capitations with values of 1.34 and 1.13 and districts 8 and 4 have the least capitations with values of 0.08 and 0.10 square meters for each person, respectively. In case of educational usage, districts 3 and 1 have the most capitations and districts 12 and 7 have the least capitations. In case of spot usage, districts 2 and 12 have the most capitations and districts 10 and 11 have the least capitations. In case of religious cultural usage, districts 3 and 5 have the most capitations with values of 2.53 and 1.39 and districts 8 and 4 have the least capitations with values of 0.17 and 0.19 square meters per person. Then, districts 4 and 9 have the most capitations of entertaining touristic usage and districts 10 and 2 have the least values. In case of vocational and higher education, district 5 has the most value; meanwhile, districts 9 and 11 have no such usage. Districts 6 and 13 have the most and districts 12 and 5 have the least capitations for urban equipments' usage. In case of industrial and workshop usage, district 12 has the most capitations with value 17.84 and district 13 has the least capitations with value 0.26 . Districts 12 and 2 have the most capitations of transportation and storage usage and districts 5 and 4 have the least capitations for this usage. The most value of capitations for disciplinary official usage belongs to districts 6 and 5 and the least value belongs to district 9 . Districts 13 and 10 have the most and the least capitations of public services, respectively. In addition, districts 3 and 1 have the most and districts 13 and 8 have the least capitations of mixed commercial usage. The most capitations of crossovers and pathways are for districts 2 and 6 with values of 14.24 and 12.45, respectively and the least capitations belong to districts 8 and 10 with values of 4.33 and 5.86 square meters per person, respectively. On the other hand, based on the urban development plan, the most capitations of green space per person belong to districts 2 and 5 with values of 31.74 and 25.20 and the least capitations belong to districts 3 and 8 with values of 5.61 and 4.54 square meters per person. Districts 5 and 4 have the most and the least capitations of health-remedial usage, respectively. In case of educational usage, districts 2 and 9 have the most and districts 5 and 4 have the least capitations, respectively. Also, with values of 1.17 and 1.12, districts 11 and 2 have the most and with values of 0.28 and 0.42 square meters per person, districts 6 and 10 have the least capitations of sport usages, respectively. District 6 has the most and district 8 ha the least capitations of religious-cultural usage in the urban development plan. In addition, the most capitations of parking lot will be in districts 1 and 5. In case of entertaining touristic usage, the most capitations will be in districts 3 and 12 and the least capitations will be in districts 4 and 7 . District 5 has the most capitations of vocational and higher education in the urban development planning with value of 10.45. the most and the least capitations of urban equipments will be in districts 13 and 5, respectively. District 12 has the most capitations of transportation and storage usage. The most capitations of disciplinary official usage will be in districts 6 and 5. In addition, districts 6 and 7 have the most and the least capitations of public services in the urban development planning, respectively. Districts 2 and 3 will have the most and the least capitations of mixed commercial usage, respectively. In case of crossovers and pathways, districts 2 and 6 will have the most capitations with values of 12.15 and 10.58 and districts 8 and 10 will have the least capitations with values of 3.72 and 4.59 , respectively. Generally, based on capitations of urban services' usages in the urban development plan, which is presented in table no. 1, it is specified that in 54\% 
of urban districts in Isfahan, capitations of green spaces is reduced. In addition, in $23 \%$ of districts, health-remedial capitations, in $38 \%$ of districts, entertaining touristic capitations, in $46 \%$ of districts, vocational and higher education capitations and in $85 \%$ of districts, industrial and workshop capitations are reduced in comparison to the current condition.

Table 1a. Status of the research indicators (capitations of urban services' usages) in detached urban districts of Isfahan (capitations of each person in $\mathrm{m}^{2}$ )

\begin{tabular}{lllllllllll}
\hline \multirow{2}{*}{$\begin{array}{l}\text { distri } \\
\text { ct }\end{array}$} & green space & \multicolumn{3}{c}{ Health-remedial } & \multicolumn{2}{c}{ Educational } & Sport & \multicolumn{3}{c}{$\begin{array}{l}\text { Religious-cultur } \\
\text { al }\end{array}$} \\
\cline { 2 - 11 } & Available & $\begin{array}{l}\text { propos } \\
\text { ed }\end{array}$ & $\begin{array}{l}\text { Availa } \\
\text { ble }\end{array}$ & $\begin{array}{l}\text { propos } \\
\text { ed }\end{array}$ & $\begin{array}{l}\text { Availa } \\
\text { ble }\end{array}$ & $\begin{array}{l}\text { propos } \\
\text { ed }\end{array}$ & $\begin{array}{l}\text { Availa } \\
\text { ble }\end{array}$ & $\begin{array}{l}\text { propos } \\
\text { ed }\end{array}$ & $\begin{array}{l}\text { Availa } \\
\text { ble }\end{array}$ & $\begin{array}{l}\text { Propos } \\
\text { ed }\end{array}$ \\
\hline 1 & 5.35 & 8.37 & 1.04 & 0.78 & 1.82 & 2.34 & 0.41 & 0.79 & 1.28 & 1.26 \\
2 & 43 & 31.74 & 0.14 & 0.3 & 1.16 & 2.49 & 0.93 & 1.12 & 0.59 & 0.73 \\
3 & 5.4 & 4.54 & 1.13 & 0.73 & 2.1 & 1.57 & 0.31 & 0.45 & 2.53 & 1.89 \\
4 & 11.3 & 9.58 & 0.1 & 0.11 & 1.04 & 1.08 & 0.43 & 0.72 & 0.19 & 0.3 \\
5 & 21.74 & 25.2 & 1.34 & 1.56 & 0.61 & 0.71 & 0.81 & 0.94 & 1.39 & 1.61 \\
6 & 10.62 & 13.72 & 0.37 & 0.36 & 1.76 & 1.42 & 0.44 & 0.42 & 1.01 & 4.36 \\
7 and & 15.55 & 8.13 & 0.32 & 0.35 & 0.6 & 1.24 & 0.48 & 0.93 & 0.25 & 0.52 \\
14 & & & & & & & & & \\
8 & 10.92 & 5.61 & 0.08 & 0.18 & 0.73 & 1.31 & 0.22 & 0.83 & 0.17 & 0.28 \\
9 & 28.26 & $18: 04$ & 0.16 & 0.18 & 1.06 & 2.36 & 0.74 & 1.01 & 0.51 & 0.68 \\
10 & 6.9 & 9.08 & 0.12 & 0.21 & 1.08 & 1.25 & 0.06 & 0.28 & 0.38 & 0.33 \\
11 & 24.94 & $10: 41$ & 0.14 & 0.34 & 0.65 & 2.14 & 0.1 & 1.17 & 0.37 & 0.62 \\
12 & 6.82 & 8.12 & 0.14 & 0.23 & 0.51 & 1.09 & 0.89 & 0.87 & 0.44 & 0.51 \\
13 & 13.73 & 15.91 & 0.19 & 0.22 & 1.17 & 1.72 & 0.21 & 0.82 & 0.31 & 0.36 \\
\hline
\end{tabular}

Table 1b. Status of the research indicators (capitations of urban services' usages) in detached urban districts of Isfahan (capitations of each person in $\mathrm{m}^{2}$ )

\begin{tabular}{|c|c|c|c|c|c|c|c|c|c|c|}
\hline \multirow{2}{*}{$\begin{array}{l}\text { distr } \\
\text { ict }\end{array}$} & \multicolumn{2}{|c|}{ Parking lot } & \multicolumn{2}{|c|}{$\begin{array}{l}\text { Entertaining } \\
\text { touristic }\end{array}$} & \multicolumn{2}{|c|}{$\begin{array}{l}\text { Vocational and } \\
\text { Higher education }\end{array}$} & \multicolumn{2}{|c|}{$\begin{array}{l}\text { Urban } \\
\text { equipments }\end{array}$} & \multirow{2}{*}{$\begin{array}{l}\begin{array}{l}\text { Industrial } \\
\text { workshop }\end{array} \\
\text { Available }\end{array}$} & \multirow{2}{*}{$\begin{array}{l}\text { and } \\
\begin{array}{l}\text { Propo } \\
\text { sed }\end{array}\end{array}$} \\
\hline & $\begin{array}{l}\text { Availa } \\
\text { ble }\end{array}$ & $\begin{array}{l}\text { propos } \\
\text { ed }\end{array}$ & $\begin{array}{l}\text { Availa } \\
\text { ble }\end{array}$ & $\begin{array}{l}\text { propos } \\
\text { ed }\end{array}$ & $\begin{array}{l}\text { Availa } \\
\text { ble }\end{array}$ & $\begin{array}{l}\text { propos } \\
\text { ed }\end{array}$ & $\begin{array}{l}\text { Availa } \\
\text { ble }\end{array}$ & $\begin{array}{l}\text { propos } \\
\text { ed }\end{array}$ & & \\
\hline 1 & - & 0.44 & 0.16 & 0.25 & 0.73 & - & 0.15 & 0.45 & 2.23 & - \\
\hline 2 & - & - & 0.01 & 0.05 & 0.14 & 0.17 & 0.26 & 0.36 & 5.34 & - \\
\hline 3 & - & 0.23 & 0.23 & 0.51 & 0.34 & 0.02 & 0.62 & 0.14 & 1.21 & - \\
\hline 4 & - & 0.04 & 2.26 & 0.01 & 0.04 & 0.01 & 0.13 & 0.12 & 1 & - \\
\hline 5 & 0.31 & 0.35 & 0.18 & 0.21 & 9.01 & $10: 45$ & 0.04 & 0.04 & - & - \\
\hline 6 & - & 0.2 & 0.3 & 0.12 & 1.44 & 1.06 & 6.96 & 1.07 & 1.68 & - \\
\hline $\begin{array}{c}7 \\
\text { and } \\
14\end{array}$ & - & 0.19 & 0.02 & 0.02 & 0.25 & 0.29 & 0.09 & 0.18 & 1.23 & 0.29 \\
\hline 8 & - & 0.22 & 0.32 & 0.25 & 0.01 & 0.01 & 0.09 & 0.85 & 1.14 & - \\
\hline 9 & - & 0.02 & 1.48 & 0.17 & 0.003 & - & 0.12 & 0.15 & 1.37 & 0.13 \\
\hline 10 & - & 0.12 & 0.01 & 0.07 & - & - & 0.09 & 0.09 & 7.11 & 1.2 \\
\hline 11 & - & 0.2 & 0.1 & 0.06 & 0.004 & - & 0.29 & 0.21 & 2.89 & - \\
\hline 12 & - & 0.34 & 0.05 & 0.21 & 0.21 & 0.25 & 0.03 & 0.17 & 17.84 & $13: 58$ \\
\hline 13 & 0.06 & 0.07 & 0.16 & 0.49 & 0.18 & 0.21 & 3.82 & 4.43 & 0.26 & 0.3 \\
\hline
\end{tabular}

Source: Naghsh-e-Jahan Pars Consulting Engineers, 2014. 
Table 1c. Status of the research indicators (capitations of urban services' usages) in detached urban districts of Isfahan (capitations of each person in $\mathrm{m}^{2}$ )

\begin{tabular}{|c|c|c|c|c|c|c|c|c|c|c|c|c|}
\hline \multirow{2}{*}{$\begin{array}{l}\text { dist } \\
\text { rict }\end{array}$} & \multicolumn{2}{|c|}{$\begin{array}{c}\text { Transportation } \\
\text { and Storage }\end{array}$} & \multicolumn{2}{|c|}{$\begin{array}{c}\text { Disciplinary } \\
\text { official }\end{array}$} & \multicolumn{2}{|c|}{$\begin{array}{c}\text { Public } \\
\text { Services } \\
\end{array}$} & \multicolumn{2}{|c|}{$\begin{array}{l}\text { mixed } \\
\text { immercial }\end{array}$} & \multicolumn{2}{|c|}{$\begin{array}{c}\text { Crossovers } \\
\text { and pathways }\end{array}$} & \multicolumn{2}{|c|}{ Other } \\
\hline & $\begin{array}{c}\text { Avail } \\
\text { able }\end{array}$ & $\begin{array}{c}\text { propo } \\
\text { sed }\end{array}$ & $\begin{array}{c}\text { Avail } \\
\text { able }\end{array}$ & $\begin{array}{c}\text { propo } \\
\text { sed }\end{array}$ & $\begin{array}{c}\text { Avail } \\
\text { able }\end{array}$ & $\begin{array}{c}\text { propo } \\
\text { sed }\end{array}$ & $\begin{array}{c}\text { Avail } \\
\text { able }\end{array}$ & $\begin{array}{c}\text { propo } \\
\text { sed }\end{array}$ & $\begin{array}{c}\text { Avail } \\
\text { able }\end{array}$ & $\begin{array}{c}\text { propo } \\
\text { sed }\end{array}$ & $\begin{array}{c}\text { Avail } \\
\text { able }\end{array}$ & $\begin{array}{c}\text { propo } \\
\text { sed }\end{array}$ \\
\hline 1 & 0.79 & - & 0.86 & 0.78 & 0.16 & - & 5.01 & 1.76 & 9.28 & 8.15 & $17: 54$ & 4.54 \\
\hline 2 & 1.61 & - & 0.1 & 0.03 & 0.07 & 0.52 & 1.26 & 1.31 & $14: 24$ & $12: 15$ & 55.76 & 3.85 \\
\hline 3 & 1.28 & - & 1.97 & 1.61 & 0.1 & - & 5.72 & 5.77 & 6.24 & 5.55 & 13:04 & $10: 55$ \\
\hline 4 & 0.21 & 0.1 & 1.12 & 1.18 & 0.08 & 0.5 & 0.6 & 1.9 & 5.96 & 4.73 & 31.14 & 4.08 \\
\hline 5 & 0.02 & 0.02 & $14: 45$ & 16.75 & 0.21 & 0.24 & 1.24 & 1.44 & 6.13 & 7.15 & - & - \\
\hline 6 & 1.48 & 0.57 & 34.83 & 19.87 & 0.08 & 0.96 & 1.79 & 1.81 & $12: 45$ & $10: 58$ & 24.56 & - \\
\hline $\begin{array}{c}7 \\
\text { and } \\
14\end{array}$ & 0.57 & 0.02 & 0.47 & 0.31 & 0.02 & 0.05 & 0.77 & 2.18 & 6.68 & 5.67 & 14.99 & 2.67 \\
\hline 8 & 0.69 & 0.29 & 0.15 & 0.13 & 0.06 & 0.07 & 0.6 & 2.65 & 4.33 & 3.72 & $13: 03$ & 2.21 \\
\hline 9 & 0.52 & - & 0.07 & 0.09 & 0.07 & - & 1.86 & 1.33 & 8.18 & 6.58 & 53.79 & 4.28 \\
\hline 10 & 0.26 & 0.04 & 0.16 & 0.04 & 0 & 0.9 & 0.96 & 1.46 & 5.86 & 4.59 & 9.74 & 2.3 \\
\hline 11 & 0.56 & - & 0.41 & 0.35 & 0.13 & 0.14 & 1.72 & 2.67 & 6.2 & 4.88 & 44.59 & 3.84 \\
\hline 12 & 2.41 & 3.24 & 0.79 & 0.57 & 0.15 & 0.05 & 0.71 & 4.45 & 9.3 & 8.59 & 24.46 & 0.19 \\
\hline 13 & 0.38 & 0.44 & 1.14 & 1.32 & 0.52 & 0.6 & 0.45 & 1.54 & 7.81 & 6.73 & 33.95 & $12: 49$ \\
\hline
\end{tabular}

Source: Naghsh-e-Jahan Pars Consulting Engineers, 2014.

\subsection{Third Step: Approach of Distribution of Indicators Using Coefficient of Dispersion}

In this stage, using SPSS software and calculating this indicator in COMPUTE section, it is specified that distribution of $50 \%$ of indicators (capitations of urban services' usages) are imbalanced and unsustainable in "current condition" and $40 \%$ of them are imbalanced and unsustainable in "urban development plan". Therefore, it is specified that distribution of indicators (capitations of urban services' usages) in "urban development plan" is still far from ideal situation but it became a little more balanced and more sustainable. According to this fact, in "current condition", the most part of imbalance and lack of sustainability is in distribution of parking lot, vocational and higher educational, disciplinary-official and urban equipments with values of 3.03, 2.58, 2.29, 2.12 , respectively. This fact shows imbalanced distribution and shortage of thee indicators (capitations of these usages) in city of Isfahan. In addition, according to "urban development plan", there is the least balanced and sustainable distribution in industrial-workshop, vocational and higher education, transportation and storage and disciplinary-official indicators with values of 3.13, 2.99, 2.44 and.03, respectively; it shows imbalanced distribution and shortage of these indicators (capitations of these usages) in future of city of Isfahan.

\subsection{Fourth Step: Determination of Weight and Importance of Indicators Using Entropy Method}

In this stage and based on Entropy method, using EXCEL software, coefficient of Entropy and weights of indicators (capitations of urban services' usages) is calculated. Therefore, it is specified that parking lot, vocational/higher education and disciplinary-official indicators have the highest weights and importance with values of $0.17,0.14$ and 0.11 , respectively; and crossovers and pathways, educational and green spaces have the least weights and importance in sustainability and prosperity of urban services' usages in Isfahan with values of $0.004,0.01$ and 0.02 , respectively. In addition, in urban development plan, industrial-workshop, vocational/higher education, transportation and storage, disciplinary-official indicators had the highest weights and importance with values of $0.19,0.17,0.14$ and 0.12 , respectively; and crossovers/pathways, educational, sport and mixed commercial had the least weights and importance in sustainable development of capitations of urban services' usages in Isfahan with value of 0.01 .

\subsection{Fifth Step: Evaluation of Status of Sustainable Development in City of Isfahan Using TOPSIS Model}

In resume of the research process and based on weights on Entropy coefficient, status of sustainable development for metropolis of Isfahan is evaluated and analyzed by detaching its urban districts and based on the research indicators (capitations of urban services' usages using TOPSIS model. Therefore, the analysis stage is 
conducted using TOPSIS SOLVER software and its results are provided in table no. 2. In addition, findings of this analysis got spatial dimensions using ARC GIS and its results are provided in Figure 1 and map no.2 at two levels of "current condition" and "urban development plan". Therefore, it is specified that value of TOPSIS scores in urban development plan in comparison to current condition are reduced in about $77 \%$ of districts. The most reductions are related to urban districts of $9,4,11$ and 2 with $71,66,52$ and $45 \%$ reduction, respectively. While, only in districts of 12,8 and 10 there is increasing values as 116,26 ad $8 \%$, respectively. According to values in table no. 2, it is specified that in "current condition", districts of 5 and 5 are very prosperous, districts of 12 and 13 are prosperous, districts of 1,2, 3, 4 and 9 are fairly prosperous, districts of 10 and 11 are less prosperous and districts of 7,14 and 8 are much less prosperous. On the other hand, based on "urban development plan", districts of 5 and 12 are very prosperous, districts of 6 and 13 are prosperous, districts of 3 and 10 are fairly prosperous, districts of 1,2, 4 and 8 are less prosperous and districts of 7, 14, 9 and 11 are much less prosperous. Therefore, in "current condition", $15 \%$ of urban districts in Isfahan are very prosperous, $15 \%$ are prosperous, $37 \%$ are fairly prosperous, $15 \%$ are less prosperous and $18 \%$ are much less prosperous. On the other hand, based on "urban development plan", $15 \%$ of urban districts of Isfahan are very prosperous, 15\% are prosperous, $15 \%$ are fairly prosperous, $30 \%$ are less prosperous and $25 \%$ are much less prosperous.

Therefore, according to comparing mentioned values, it is specified that percentages of "fairly prosperous" districts in current conditions are reduced in urban development plan and percentages of "less prosperous and much less prosperous" districts are added. Therefore, in current condition, 33\% of urban districts in Isfahan, are "less and much less prosperous" and 37\% of them are "fairly prosperous"; only $30 \%$ of urban districts in Isfahan are "prosperous and very prosperous". This condition gets worse in urban development planning. In urban development planning of Isfahan, 55\% of urban districts in this city are "less and much less prosperous" and 15\% are "fairly prosperous" and only $30 \%$ are "prosperous and very prosperous".

Table 2. Status of Sustainable Development of metropolis of Isfahan using TOPSIS model

\begin{tabular}{|c|c|c|c|c|c|c|}
\hline & TOPSIS & TOPSIS rank & TOPSIS & TOPSIS rank & $\begin{array}{l}\text { Status of } \\
\text { development }\end{array}$ & Sustainable \\
\hline District & $\begin{array}{l}\text { rank for } \\
\text { current } \\
\text { condition }\end{array}$ & $\begin{array}{l}\text { Tor } \\
\text { development } \\
\text { plan }\end{array}$ & $\begin{array}{l}\text { rank for } \\
\text { current } \\
\text { condition }\end{array}$ & $\begin{array}{l}\text { Tor Urban } \\
\text { development } \\
\text { plan }\end{array}$ & $\begin{array}{l}\text { current } \\
\text { condition }\end{array}$ & $\begin{array}{l}\text { Urban } \\
\text { development } \\
\text { plan }\end{array}$ \\
\hline 1 & 0.124 & 0.075 & 9 & 7 & fairly & $\begin{array}{l}\text { Less } \\
\text { prosperous }\end{array}$ \\
\hline 2 & 0.133 & 0.073 & 8 & 8 & fairly & $\begin{array}{l}\text { Less } \\
\text { prosperous }\end{array}$ \\
\hline 3 & 0.159 & 0.105 & 6 & 5 & Fairly & fairly \\
\hline 4 & 0.180 & 0.061 & 5 & 10 & fairly & $\begin{array}{l}\text { Less } \\
\text { prosperous }\end{array}$ \\
\hline 5 & 0.594 & 0.434 & 1 & 2 & $\begin{array}{l}\text { Very } \\
\text { prosperous }\end{array}$ & $\begin{array}{l}\text { Very } \\
\text { prosperous }\end{array}$ \\
\hline 6 & 0.385 & 0.287 & 2 & 3 & $\begin{array}{l}\text { Very Less } \\
\text { prosperous }\end{array}$ & prosperous \\
\hline $\begin{array}{l}7 \text { and } \\
14\end{array}$ & 0.047 & 0.037 & 13 & 13 & $\begin{array}{l}\text { Much Less } \\
\text { prosperous }\end{array}$ & $\begin{array}{l}\text { Much Less } \\
\text { prosperous }\end{array}$ \\
\hline 8 & 0.054 & 0.068 & 12 & 9 & $\begin{array}{l}\text { Much Less } \\
\text { prosperous }\end{array}$ & $\begin{array}{l}\text { Less } \\
\text { prosperous }\end{array}$ \\
\hline 9 & 0.140 & 0.041 & 7 & 11 & fairly & $\begin{array}{l}\text { Much Less } \\
\text { prosperous }\end{array}$ \\
\hline 10 & 0.097 & 0.105 & 10 & 6 & $\begin{array}{l}\text { Less } \\
\text { prosperous }\end{array}$ & fairly \\
\hline 11 & 0.085 & 0.041 & 11 & 12 & $\begin{array}{l}\text { Less } \\
\text { prosperous }\end{array}$ & $\begin{array}{l}\text { much Less } \\
\text { prosperous }\end{array}$ \\
\hline 12 & 0.241 & 0.520 & 4 & 1 & prosperous & $\begin{array}{l}\text { Very } \\
\text { prosperous }\end{array}$ \\
\hline 13 & 0.246 & 0.232 & 3 & 4 & prosperous & prosperous \\
\hline
\end{tabular}




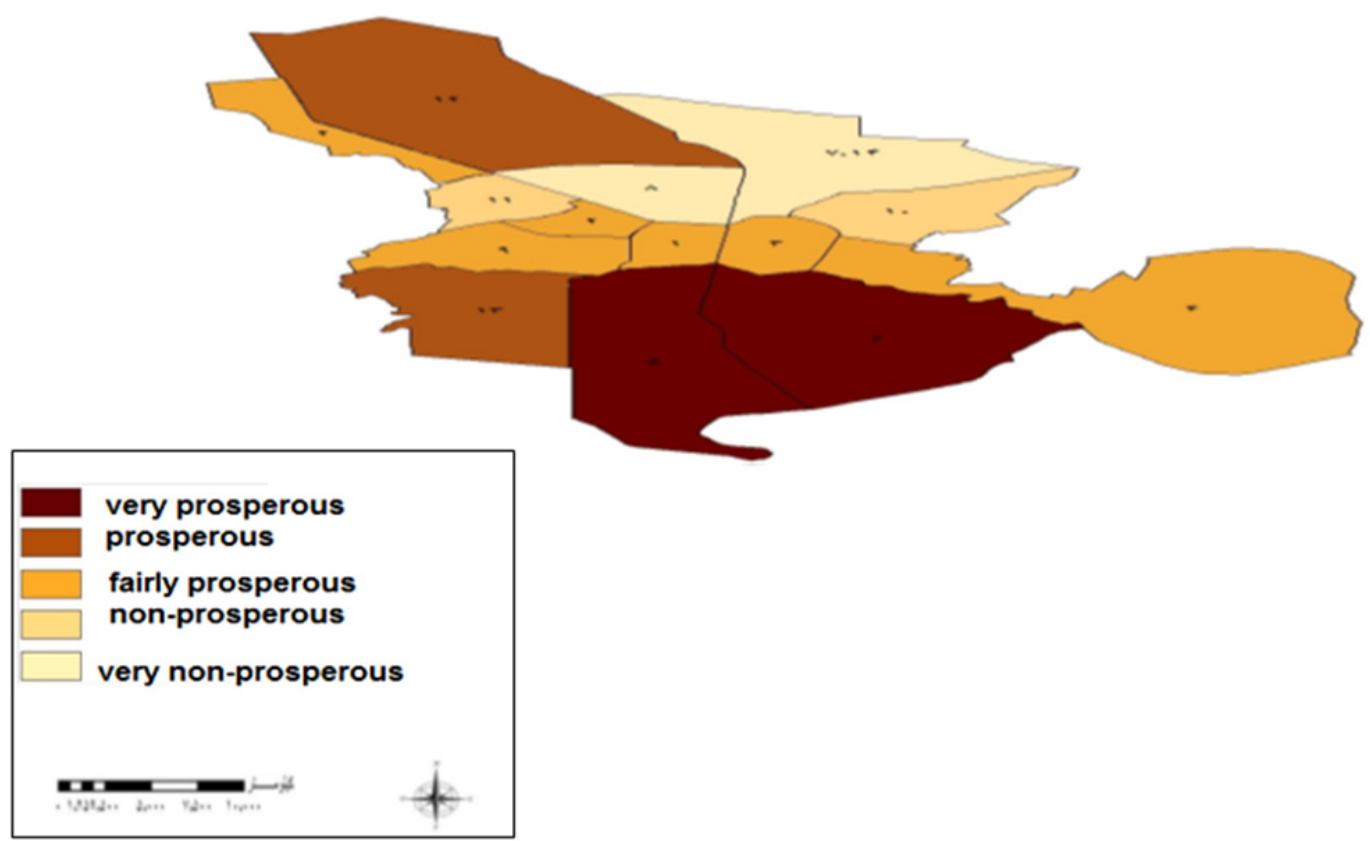

Figure 3. Status of sustainable development in metropolis of Isfahan in current condition using TOPSIS model

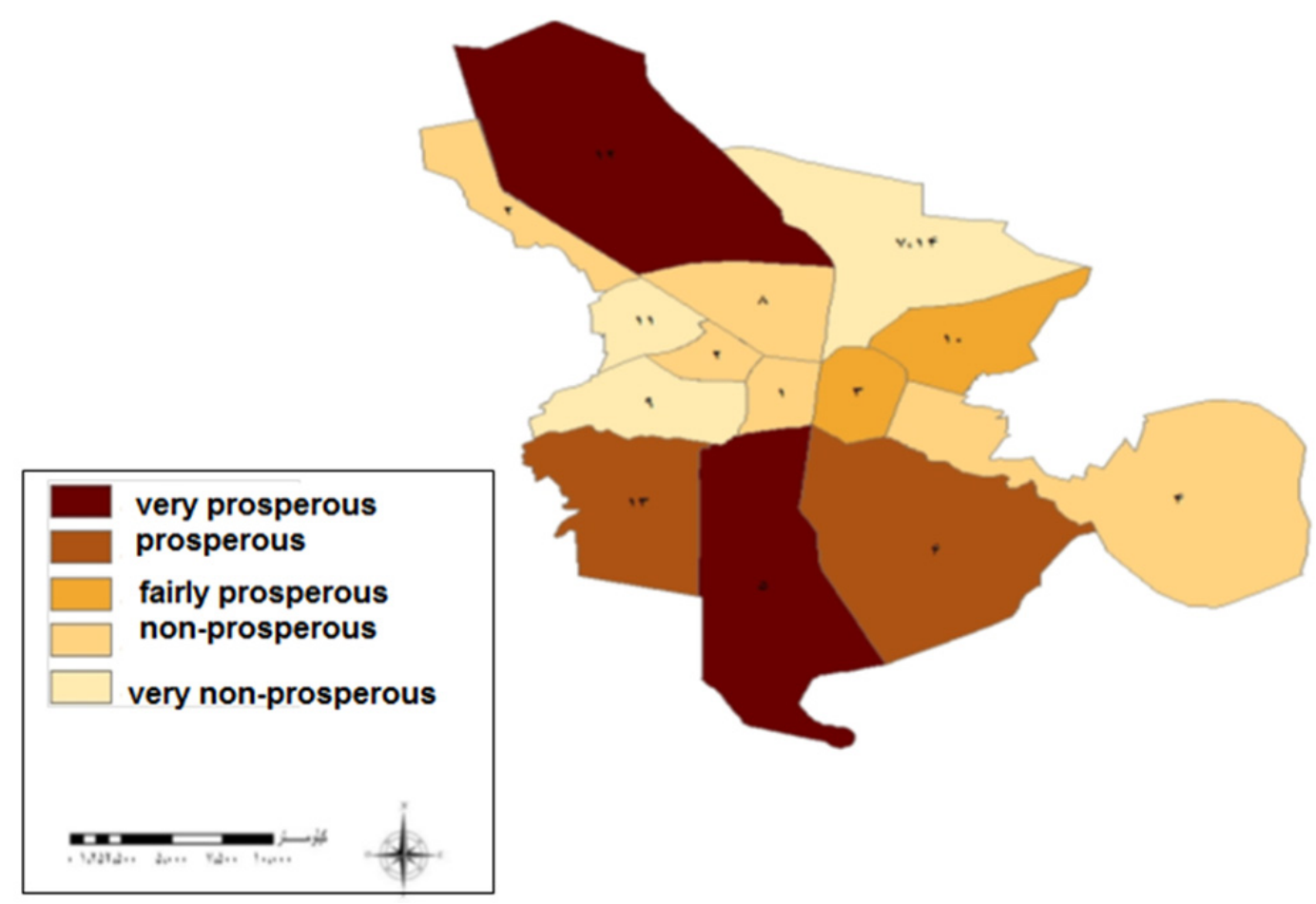

Figure 4. Status of sustainable development in metropolis of Isfahan in urban development plan using TOPSIS model

\section{Conclusion}

In this research, status of sustainable development in metropolis of Isfahan is analyzed and evaluated at two levels of "current condition" and "urban development plan" in a systematic process. According to results and findings of the research, it is specified that in "current condition", districts 5 and 6 are very prosperous (15\%), districts 12 and 13 are prosperous (15\%), districts 1,2,3,4 and 9 are fairly prosperous (37\%), districts 10 and 11 
are less prosperous (15\%) and districts 7, 14 and 8 are much less prosperous (18\%). On the other hand, according to "urban development plan", districts 5 and 12 are very prosperous (15\%), districts 6 and 13 are prosperous (15\%), districts 3 and 10 are fairly prosperous (15\%), districts 1, 2, 4 and 8 are less prosperous (30\%) and districts 7, 149 and 11 are much less prosperous (25\%). Therefore, based on mentioned values, it is specified that percentage of "fairly prosperous" districts in current condition is reduced in urban development plan and percentages of "less and much less prosperous" districts are increased. Therefore, in current condition, $33 \%$ of urban districts of Isfahan are "less and much less prosperous" and 37\% are "fairly prosperous"; only $30 \%$ of urban districts of Isfahan are "prosperous and very prosperous". This situation gets worse in urban development plan. In urban development plan of Isfahan, 55\% of urban districts of Isfahan are "less and much less prosperous" and 15\% are "fairly prosperous"; only $30 \%$ of urban districts in this city are "prosperous and very prosperous". This conclusion indicates that at both levels of "current condition" and "urban development planning", urban development flow of Isfahan is an unsustainable flow and most urban districts of Isfahan are much less prosperous, less prosperous or fairly prosperous; but this situation got worse in current urban development plan of Isfahan. In such a way that in this plan, more than half of "fairly prosperous" level turned to "less and much less prosperous" level and other levels are kept in similar status. According to this fact that indicators of this research are capitations of urban services' usages, it can be concluded that capitations of urban services are reduced in urban development plan and are turned to capitations of residential usages (non-service). Therefore, it seems that urban development plan is away from appropriate and sustainable condition and one of its main goals, which is spatial justices and fair distribution of public services' usages in urban districts of Isfahan; and it does not indicate relative improvement in comparison to current condition. Therefore, we cannot achieve to sustainable development and prosperity of metropolis of Isfahan in current condition and in current urban development plan. Therefore, metropolis of Isfahan is not a sustainable and prosperous city and its facilities and public services in their urban districts are not distributed balanced and sustainably and there is shortage, here. Unfortunately, this status is not improved and corrected in urban development plan of Isfahan and in this plan, metropolis of Isfahan is an unsustainable and non-prosperous city, too; and it will be a city without social and spatial justice in fair distribution of urban and public services at level of urban districts. It seems that "change" in approach of planning and preparing urban development plan of Isfahan is an emergency issue and a strategic necessity with emphasis on sustainable development and by change from comprehensive planning (detailed and comprehensive plans) toward strategic planning suing preparation of city development strategy (CDS).

\section{Recommendations}

The current urban development plan of Isfahan (detailed and comprehensive plans) has no efficiency and effectiveness on urban development and realization of spatial and social justice. Therefore, essential review in approaches and principles of the current urban development plan (detailed and comprehensive plans) is a strategic necessity in order to increasing productivity and effectiveness of these plans in development and improvement of a city. In this regard, it is necessary to plan strategically and provide city development strategy (CDS) for metropolis of Isfahan regarding urban sustainable development and it is necessary to provide and implement action plans in this framework, too.

Developing city of Isfahan should be planned and operated based on sustainable neighborhood system (neighborhood centering) with spread and pervasive public participation of citizens in process of developing and governing the city and in preparing urban development plans.

Urban management of Isfahan is spare and scattered, currently. Therefore, in order to realizing urban development plan, this urban management should turn to an integrated and sustainable urban management by having intelligent structure and improving its quality.

More budgets and financial resources should be attributed to districts 7, 14, 8, 10 and 11 (which are less and much less prosperous in current condition) and to districts 1, 2, 4 and 9 (which are less and much less prosperous in urban development plan) by urban management of Isfahan in order to create more public services.

Creating protective green spaces and huge centers of public services in city and regional scale in suburb and periphery of Isfahan city in order to compensate a part of shortage in services of less prosperous marginal districts of the city such as districts $2,4,7,14,9,10$ and 11 .

Developing and improving quality of current public services' spaces in order to increase productivity of urban services.

Spreading and developing mixed usages by combining service and residential usages in order to increase capitations of service usage in the city. 


\section{References}

Hall, P., \& Fifer, U. (2009). The urban future of 21th century, translated by Ismail Sadeghi and Nahid Safaei. Iran society of counseling engineers, Tehran.

Hamidreza, V., Ghaed Rahmati, S., \& Bastanifar, A. (2007). Investigation and distribution of urban services in spatial imbalance of population, case study: Isfahan city. Journal of Geography and development, 9.

Hataminejad, H., Rahmat Allah, F., \& Morteza, M. J. (2008). Journal of human geographic researches, 65, 71-85.

Hekmatnia, H., \& Mirnajaf, M. (2011). Application of model in geography with emphasis on urban and regional planning. Elm-e-Novin publication, second print, Yazd.

Masnavi, M. (2002). Sustainable development and new paradigms of urban development: spare city and compressed city. Environment studies journal, 31 .

Naghsh-e-Jahan Pars counseling engineers. (2014). Summary of report on review plan studies of detailed plan of Isfahan city (the new detailed plan of Isfahan city).

Pug, S. (2004). Sustainable cities in under-developing countries. Publication of center of architecture and urbanization studies and researches, first print, Tehran.

Saberi, H., Asghar, Z., \& Jamal, M. (2012). Prioritizing city development strategies (CDS) using analysis hierarchical process (AHP), case study: metropolis of Isfahan. Journal of geographical space, 39.

Shokouei, H. (1999). Applied geography and geographic schools. Cartography and geography institute of Gitashenasi, Tehran.

Statistics journal of Isfahan city. (2013). Municipality of Isfahan.

Taghvaei, M., \& Azam, S. (2013). Urban sustainable development and some factors effecting on it. Journal of urban sociologic studies, 6.

Taghvaei, M., \& Hosein, K. (2011). grading urban neighborhoods based on prosperity of urban facilities and services using TOPSIS technique (case study: neighborhoods of Abadeh town). Journal of urban planning and research, 5 .

Taghvaei, M., Hamidreza, V., \& Rana, Sh. (2011). Analysis of inequalities in regional development in Iran. Journal of human geographic researches, 78.

Tghvaei, M., Hossein, H., \& Jabbar, A. (2014). Urban development strategy with emphasis on empowering urban neighborhoods, case study: neighborhood of Akbarabad in Yazd. Journal of space geographic preparation, 15.

Zahrabi, M., \& Reza, M. M. (2006). Analysis of developing indicators for 11 districts of Isfahan. Proceedings of urban planning and management conference. University of Firdausi, Mashhad.

\section{Copyrights}

Copyright for this article is retained by the author(s), with first publication rights granted to the journal.

This is an open-access article distributed under the terms and conditions of the Creative Commons Attribution license (http://creativecommons.org/licenses/by/3.0/). 